\title{
Heavy Mineral Distribution in the Lokoja and Patti Formations, Southern Bida Basin, Nigeria: Implications for Provenance, Maturity and Transport History
}

\author{
Razširjenost težkih mineralov v formacijah Lokoja in Patti: \\ poreklo, zrelost in zgodovina transporta
}

Bankole, S. I. ${ }^{*}$ Akinmosin, A., Omeru, T. and Ibrahim, H. E.

University of Lagos, Faculty of Science, Department of Geosciences, Akoka, Lagos, Nigeria

*sbankole@unilag.edu.ng

\begin{abstract}
Heavy mineral component of 13 samples from the Lokoja and Patti Formations, Bida Basin have been studied for their textural characteristics, compositional abundance, maturity and provenance determinations. The suite of heavy minerals encountered is classified as opaque and non-opaque constituents. The non-opaque components include zircon, tourmaline, rutile, garnet, staurolite, epidote, kyanite, titanite, lawsonite, cassiterite, sillimanite, hornblende, hypersthene and andalusite. The assemblage is generally dominated by zircon and tourmaline in the two formations. The constituent heavy minerals identified are dominated by ultra-stable and stable classes, whereas the ZTR indices indicate mineralogical immaturity coupled with textural immaturity of the constituent grains. This suggests the possible dominance of chemical weathering of the source rock. The suites of minerals recovered have been linked to both metamorphic and non-metamorphic crystalline rock origins.
\end{abstract}

Key words: heavy mineral, zircon, tourmaline, mineralogical analysis

\section{Povzetek}

Komponente težkih mineralov trinajstih vzorcev iz formacij Lokoja in Patti v bazenu Bida so bile preiskovane glede na teksturne lastnosti, pogostost, zrelost in določitve porekla. Nabor proučevanih težkih mineralov je razvrščen na neprozorne in prozorne sestavne dele. Prozorne komponente vključujejo cirkon, turmalin, rutil, granat, stavrolit, epidot, kianit, titanit, lavsonit, kasiterit, silimanit, rogovačo, hipersten in andaluzit. V sestavi formacij večinoma prevladujeta cirkon in turmalin. Med težkimi minerali prevladujejo ultra stabilni in stabilni razredi, medtem ko indeksi ZRC izkazujejo mineraloško nezrelost, povezano s teksturno nezrelostjo sestavnih zrn. To nakazuje na mogočo prevlado kemijskega preperevanja matične kamnine. Pridobljeni minerali so povezani tako z metamorfnim kot ne metamorfnim kristalnim nastankom.

Ključne besede: težki minerali, cirkon, turmalin, mineraloška analiza 


\section{Introduction}

The Intracratonic Bida Basin (Nupe or Middle Niger Basin) is one of the inland sedimentary basins of Nigeria [1], located roughly at the mid-central Nigeria (Figure 1). It is a northwest-southeast trending basin contiguous with the Anambra Basin. It extends from Kontagora, Niger State to Dekina, Benue State with a length of about $400 \mathrm{~km}$ and a width approximating $160 \mathrm{~km}$ [2]. Sediment accumulation in the basin commenced from Campanian and continued through the Maastrichtian [3] with fills ranging between 3.5 and $4.5 \mathrm{~km}$ thickness $[4,5]$ at the central part of the basin. Several research papers have been published on the evolution and stratigraphy of the basin.

Rift origin in connection with the aulacogen Benue Trough of Nigeria consequence to the separation of the South American and African continents in the Late Jurassic has been suggested for the Bida Basin [6-8]. This rifting resulted in the generation of series of horst and graben structures that characterizes the floor of the Bida Basin.

On the basis of geographical and lateral facies variation, the basin has been divided into the northern and southern sub-basins (Figure 1). In the southern Bida sub-basin, the oldest sedimentary unit, lying non-conformably on the Precambrian to Lower Paleozoic crystalline basement complex is the fluviatile Lokoja Formation (Figure 2). Patti Formation conformably overlies the Lokoja Formation (Figure 3). Observations at the base of Agbaja Plateau and also at the Ahoko Village mine indicate mixed marine and continental deposition environments for the Patti Formation. Literature accounts revealed that the formation consists of sandstones, siltstones, mudstones and shale in intercalation with bioturbated ironstones $[9,10]$. The marine series of the Patti Formation is exposed at an abandoned mine in Ahoko Village along Lokoja-Abuja Highway. This unit, which constitutes part of the shale member of the Patti Formation has been extensively reviewed, described and reported by several authors [8, 10, 11-13]. The Agbaja Ironstone Formation caps the sequence of sediments in the southern Bida Sub-basin. Agbaja Formation is an intercalation of claystones, sandstones and

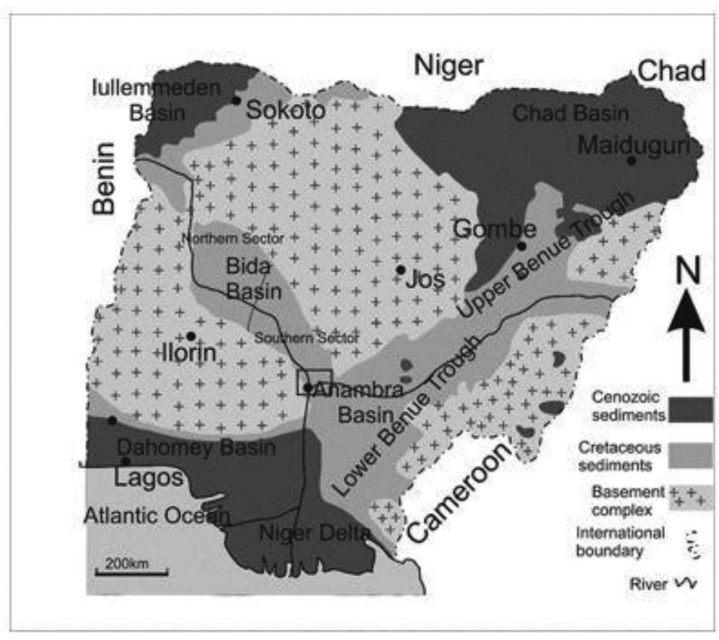

Figure 1: Geological map of Nigeria. Box indicates the study area.

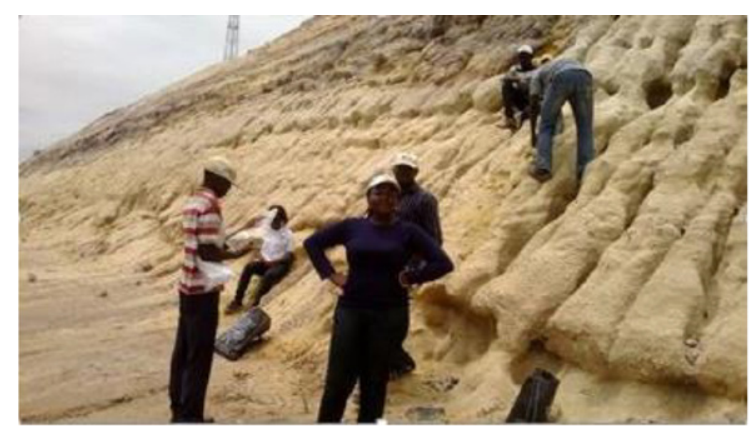

Figure 2: Section of the Lokoja Formation exposed at Okumi, along the Lokoja-Abuja Highway.

oolitic/massive ironstones. Ladipo et al. [14] interpreted the sequence of the formation as abandoned channel sands and overbank deposits with marine influence resulting in the formation of the massive concretionary and oolitic ironstones.

In the present study, we report on the distribution and concentration of heavy minerals in the Lokoja and Patti Formations. On the basis of these, attempt is made to infer the provenance, maturity and transport history of the sediments of the formations. Detrital sediments are products of pre-existing igneous, metamorphic and also sedimentary rocks. These rocks are composed of diverse detrital minerals with some being classified as placer minerals. The latter are generally highly mechanically resistant and survive the usual complex transportation processes from source areas to the depocen- 


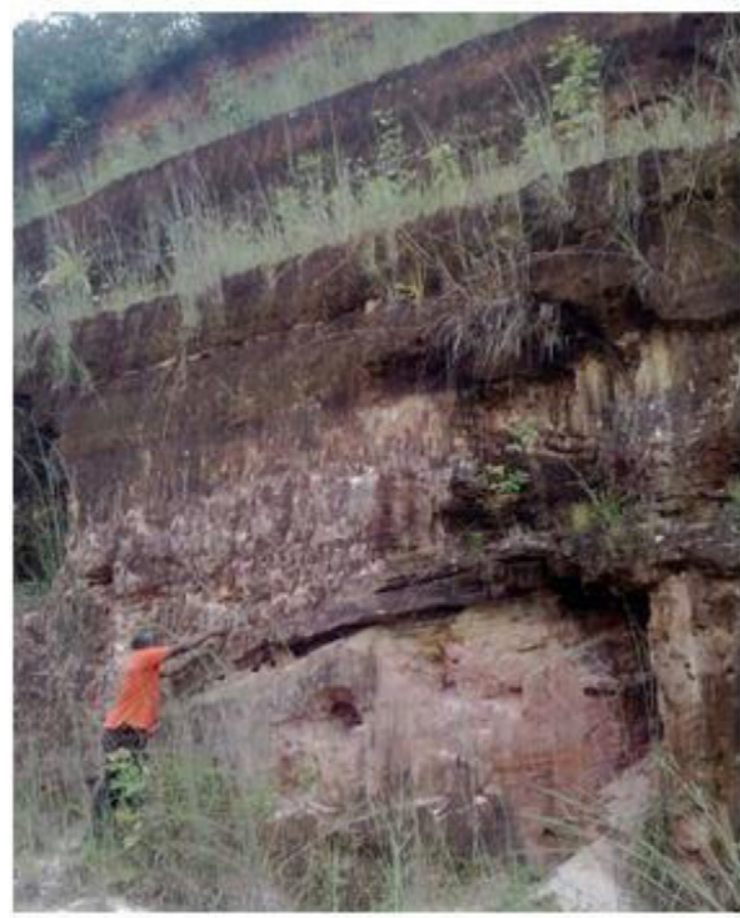

Figure 3: Section of the Patti Formation exposed near the Agbaja Plateau along Lokoja - Agbaja road. The capping rock (uppermost section) in this outcrop is the lower unit of Agbaja Ironstone Formation.

ters. These characteristics have allowed the use of heavy minerals in the study of sediment provenance, maturity and transport history. This method has been widely applied in fluvial $[15,16]$, coastal-shallow marine $[17,18]$, deep marine [19] depositional environments.

\section{Materials and Methods}

\section{Materials}

In total, 13 sediment samples (six from Lokoja Formation and seven from Patti Formation) were subjected to heavy mineral analysis. The analysis was carried out at the Sedimentological Laboratory, Department of Geosciences, University of Lagos, Nigeria.

\section{Methods}

Heavy mineral analysis in this study followed the procedure of Suzuki [20] and Mange and Maurer [21] for heavy mineral separation. The heavy liquid, Bromoform (CHBr3) with a density of $2.9 \mathrm{~g} / \mathrm{cc}$ and viscosity of 0.068 poises was used. The samples were air-dried for a week to dispel any moisture as they were collected during the rainy season. Thereafter, the sediments were gently disaggregated by squeezing between fingers and filter paper or mortar and pestle in the case of hard samples to liberate individual grains. Each sample of $70 \mathrm{~g}$ was weighed and sieved to obtain 62.5-500 microns size grains. The individual sample was then poured into the bromoform and stirred thoroughly to free the samples of air bubbles. The particles were allowed to settle for about 20 minutes, stirring periodically to prevent the particles from adhering to funnel wall. The heavy crop was repeatedly washed in excess acetone and distilled water and air-dried and labelled. In all, 13 permanent mounts were made on slides using coupled resin. Mineral identification on the basis of their optical properties as proposed by Mange and Maurer [21] and Lindholm [22] was conducted on the samples.

More than 100 grains were counted from each slide for statistical analysis. Rock fragments, unidentifiable grains as well as authigenic and opaque minerals were excluded from the total sum to obtain uniform, comparable data on transparent assemblages for the characterization of mineralogical provinces. The sum of transparent minerals was recalculated to a value of $100 \%$ and the abundance of each heavy mineral species was scaled accordingly. The "ZTR" index which is the combined percentage of zircon, tourmaline and rutile among the nonopaque heavy minerals, omitting micas and authigenic species was calculated using [23] formula below:

$Z R T$ index $=\frac{\text { Zircon }+ \text { Tourmaline }+ \text { Rutile }}{\text { Non }- \text { opaque }} \times 100$

ZTR index was calculated for the samples to ascertain their mineralogical maturity. According to Hubert [23], ZTR index $<75 \%$ implies immature to sub-mature sediments and ZTR $>75 \%$ indicates mineralogically matured sediments.

\section{Results and Discussions}

\section{Results}

Heavy mineral concentration in the Lokoja and Patti Formations is classified into opaque and 
non-opaque constituents. The opaque components generally referred to as iron stained heavy minerals require further chemical analysis to allow investigation under petrographic microscope. This chemical analysis, however, is beyond the scope of the present investigation and no further serious attention apart from statistical consideration is accorded to this class of heavy minerals herein. The recovered nonopaque components common to the two formations include the following: zircon, tourmaline, rutile, garnet, staurolite, epidote, kyanite, titanite, lawsonite, cassiterite, sillimanite, hornblende, hypersthene and andalusite (Plates 1-14). Kyanite, cassiterite, hypersthene, staurolite, hornblende and lawsonite show rare occurrences in the Lokoja Formation, except in a sample (Lok2 S6) that has significant amount of hornblende. Also, Kyanite, titanite, hornblende and garnet show rare occurrences in the Patti Formation, kyanite occurs only in PAT S7 sample. The proportion of heavy mineral recovered to the volume of sediment analysed is generally low and may not support any significant economic prospect. Information on the proportion of the heavy minerals recovered from the two formations is provided in Tables 1 and 2 . Also, Tables 3 and 4 show the calculated ZRT\% index results.

The summary of the identification/classification criteria and the significant characteristics of each of the recovered heavy mineral are as follow:

Zircon: Zircon grains (Plates 2, 3 and 6) are prismatic, rounded to sub-rounded and sometimes contains fluid and mineral inclusions. Prismatic grains frequently showed zonation identified by fine bands parallel to the crystal boundary (Plate 2). The colourless varieties are more in abundance than the coloured varieties. The grains are easily identifiable owing to their very high relief and they are surrounded by black halo (Plates 2, 3 and 6). They show weak pleochroism and strong birefringence.

Tourmaline: Tourmaline grains (Plates 1, 2, 4 and 5) are prismatic, elongated, oval-shaped, spherical, euhedral, sub-hedral to irregular in shapes, with terminations at one or both ends of prismatic variety. Moderate relief, mineral inclusions (Plate 9) and overgrowths were frequently observed (Plate 1). Colours vary from pale to pink, dark green (Plate 4), pale yellowish, dark brown (Plate 4), very dark (almost opaque, may be iron bearing; Plates 1 and 5) and sometimes colourless. Colour zoning is frequent, pleochroism sharp and distinctive. Varicoloured varieties were also present (one portion of the grain displays striking different shades to the other).

Rutile: Rutiles (Plate 7) appeared as small and sub-rounded slender prisms with well-developed terminations or breakage patterns. A thick halo surrounds the grains because of their extremely high refractive indices. Grains are mostly brownish red to brownish black in colours and show distinct pleochroism (Plate 7).

Kyanite: Kyanite grains (Plates 8 and 12) are angular, or prismatic, dominantly colourless, weakly pleochroic (uneven coloured pleochroism) and exhibit characteristic cross-fractures and step-like features (Plates 8 and 12). The step-like uneven thickness resulted in a spectacular arrangement of the interference colours appearing in blue and grey on thicker and thinner parts, respectively.

Sillimanites: Sillimanites (Plates 9, 11 and 13) are long, slender, prismatic or irregular in shapes. Sillimanites show distinct cleavage, pleochroic (pale brown to pale yellow), parallel extinction, shows brilliant second- and third-order interference colours with yellow, green and pink as a dominant shades; slight twinkling is noticeable on rotation.

Andalusite: Andalusite (Plates 2-4, 6 and 7), mostly colourless and frequently enclose carbonaceous impurities. The rare manganoan variety, viridine which is green in colour was observed (Plate 4). They occur as prismatic, sub-rounded to angular or of irregular morphology; cleavage traces are poorly displayed. Some grains are non-pleochroic, whereas others display inhomogeneous pattern of pleochroism. Due to their irregular shape and uneven thickness, they display disorderly patterned interference colours. Weak interference colours are second-order orange and greenish blue (Plates 2-4, 6, and 7).

Garnet: Garnets (Plates 1, 3-6), easily identifiable because of their high relief and isotropic nature are euhedral, rounded, sub-rounded or irregular grains with uneven or conchoidal 
Table 1: Proportion (number of grains) of heavy minerals concentration in the sediments of Lokoja Formation.

\begin{tabular}{|c|c|c|c|c|c|c|c|c|c|c|c|c|c|c|c|c|c|}
\hline $\begin{array}{c}\text { Sample } \\
\text { Name }\end{array}$ & $S / N$ & Zrn & Tur & Rt & Grt & St & Ep & Sil & $\mathrm{Tt}$ & And & Ky & $\mathbf{M}$ & Cst & Hbl & Hyp & Lws & Opq \\
\hline $\begin{array}{c}\text { LOK1 } \\
\text { S1 }\end{array}$ & 1 & 4 & 3 & 1 & 4 & - & 4 & - & 4 & - & - & 4 & - & - & - & - & 22 \\
\hline $\begin{array}{c}\text { LOK1 } \\
\text { S2B }\end{array}$ & 2 & 5 & 13 & 1 & 1 & - & 8 & 11 & 2 & 7 & 3 & 9 & - & - & - & 3 & 236 \\
\hline $\begin{array}{c}\text { LOK1 } \\
\text { S4B }\end{array}$ & 3 & 5 & 4 & 3 & 4 & 1 & 2 & 2 & - & 5 & - & 4 & - & - & - & - & 142 \\
\hline $\begin{array}{c}\text { LOK2 } \\
\text { S2 }\end{array}$ & 4 & 11 & 9 & 3 & 8 & 1 & 5 & 3 & 3 & 1 & - & 6 & - & 1 & 1 & - & 253 \\
\hline $\begin{array}{c}\text { LOK2 } \\
\text { S6 }\end{array}$ & 5 & 6 & 3 & 4 & 2 & - & 3 & - & - & 3 & - & - & 4 & 7 & 1 & - & 245 \\
\hline $\begin{array}{c}\text { LOK2 } \\
\text { S8 }\end{array}$ & 6 & 69 & 5 & 12 & 10 & 2 & 10 & 8 & - & 3 & - & 2 & - & - & - & 3 & 1560 \\
\hline TOTAL & & 100 & 37 & 24 & 29 & 4 & 32 & 24 & 9 & 19 & 3 & 25 & 4 & 8 & 2 & 6 & 2458 \\
\hline
\end{tabular}

Note: $Z r n=$ Zircon; Tur = Tourmaline; Grt = Garnet; St = Staurolite; Ep = Epidote; Sil = Sillimanite; Tt = Titanite; And = Andalusite; Ky = Kyanite; $\mathrm{Opq}=$ Opaque, $\mathrm{Hbl}=$ Hornblende; Hyp = Hypersthene; $\mathrm{Cst}=$ Cassiterite; $L$ st = Lawsonite; $M=$ Mica. S/N: Serial Number.

Table 2: Proportion (number of grains) of heavy minerals concentrations in the sediment samples from Patti Formation.

\begin{tabular}{|c|c|c|c|c|c|c|c|c|c|c|c|c|c|c|}
\hline CODE & $\mathbf{S} / \mathbf{N}$ & Zrn & Tur & $\mathbf{R t}$ & Grt & $\mathbf{S t}$ & Ep & Sil & $\mathbf{T t}$ & And & Ку & $\mathbf{M}$ & Hbl & Opq \\
\hline PAT S1B & 1 & 27 & 10 & 1 & - & 4 & 2 & 1 & 1 & 3 & - & - & 1 & 303 \\
\hline PAT S2B & 2 & 13 & 11 & 2 & - & - & 4 & - & 3 & - & - & 8 & 3 & 54 \\
\hline PAT S5B & 3 & 4 & 4 & 2 & 1 & 6 & - & 2 & - & 3 & - & 4 & - & 201 \\
\hline PAT S7 & 4 & 10 & 9 & 2 & 4 & 13 & 10 & 8 & 4 & 8 & 2 & - & 4 & 1352 \\
\hline PAT S13 & 5 & - & - & - & - & - & - & - & - & - & - & - & - & - \\
\hline PAT S16 & 6 & - & - & - & - & - & - & - & - & - & - & - & - & - \\
\hline PAT S17B & 7 & 3 & 4 & 8 & 1 & - & - & 2 & - & 4 & - & - & - & 2420 \\
\hline TOTAL & & 57 & 38 & 15 & 6 & 23 & 16 & 13 & 8 & 18 & 2 & 12 & 8 & 4330 \\
\hline
\end{tabular}

fractures. Colours vary from pinkish brown, pale red, pale pink to colourless.

Titanite: Titanite (Plate 12) grain has a high resinous lustre. Relief shows a slight twinkling on rotation of the stage. The grain has a weak pleochroism and good cleavage. High-order interference colours in golden yellow and yellowish white.

Staurolite: Staurolite (Plates 4, 11 and 14) occurs as irregular or angular grains. Colour ranges from pale yellow, golden yellow to dark yellowish brown. They exhibit distinct pleochroism (colourless to different shades of yellow).

Epidote: Epidote (Plates 2, 6 and 8) occurs as irregularly shaped grains, yellowish green to green coloured with fairly high relief. They exhibit distinct pleochroism (colourless, pale yellow, yellowish green). 
Table 3: ZTR maturity index and individual percentage mineral of the sediment samples of Lokoja Formation.

\begin{tabular}{|c|c|c|c|c|c|c|c|c|c|c|c|c|c|c|c|c|c|c|}
\hline CODE & Zrn & Tur & Rt & Grt & St & Ep & Sil & $\mathbf{T t}$ & And & Ky & $\mathbf{M}$ & Cst & Hbl & Нyp & Lst & $\begin{array}{c}\text { TOTAL } \\
\text { NON- } \\
\text { OPAQUE }\end{array}$ & $\mathrm{Z}+\mathrm{T}+\mathrm{R}$ & $\begin{array}{l}\text { ZTR\% } \\
\text { INDEX }\end{array}$ \\
\hline $\begin{array}{l}\text { LOK1 } \\
\text { S1 }\end{array}$ & 4 & 3 & 1 & 4 & - & 4 & - & 4 & - & - & 4 & - & - & - & - & 24 & 8 & 33.3 \\
\hline $\begin{array}{c}\text { LOK1 } \\
\text { S2B }\end{array}$ & 5 & 13 & 1 & 1 & - & 8 & 11 & 2 & 7 & 3 & 9 & - & - & - & 3 & 63 & 19 & 30.2 \\
\hline $\begin{array}{l}\text { LOK1 } \\
\text { S4B }\end{array}$ & 5 & 4 & 3 & 4 & 1 & 2 & 2 & - & 5 & - & 4 & - & - & - & - & 30 & 12 & 40.0 \\
\hline $\begin{array}{l}\text { LOK2 } \\
\text { S2 }\end{array}$ & 11 & 9 & 3 & 8 & 1 & 5 & 3 & 3 & 1 & - & 6 & - & 1 & 1 & - & 52 & 23 & 44.2 \\
\hline $\begin{array}{c}\text { LOK2 } \\
\text { S6 }\end{array}$ & 6 & 3 & 4 & 2 & - & 3 & - & - & 3 & - & - & 4 & 7 & 1 & - & 33 & 13 & 39.4 \\
\hline $\begin{array}{l}\text { LOK2 } \\
\text { S8 }\end{array}$ & 69 & 5 & 12 & 10 & 2 & 10 & 8 & - & 3 & - & 2 & - & - & - & 3 & 124 & 86 & 69.4 \\
\hline TOTAL & 100 & 37 & 24 & 29 & 4 & 32 & 24 & 9 & 19 & 3 & 25 & 4 & 8 & 2 & 6 & 326 & 161 & 49.4 \\
\hline$\%$ & 30.7 & 11.3 & 7.4 & 8.9 & 1.2 & 9.8 & 7.4 & 2.8 & 5.8 & 0.9 & 7.7 & 1.2 & 2.5 & 0.6 & 1.8 & \multicolumn{3}{|c|}{$\begin{array}{l}\text { Individual mineral\% } \\
\text { abundance }\end{array}$} \\
\hline
\end{tabular}

Average ZTR\% Index $=42.8 \%$

Total Opaque $=2458$

Total Non-opaque $=326$

Total Non-opaque excluding micas $=301$

Table 4: ZTR maturity index and individual percentage mineral of the sediment samples of Patti Formation.

\begin{tabular}{|c|c|c|c|c|c|c|c|c|c|c|c|c|c|c|c|c|c|c|}
\hline CODE & Zrn & Tur & Rt & Grt & St & Ep & Sil & $\mathbf{T t}$ & And & Ky & $\mathbf{M}$ & Cst & Hbl & Нур & Lst & $\begin{array}{c}\text { TOTAL } \\
\text { NON- } \\
\text { OPAQUE }\end{array}$ & $\mathrm{Z}+\mathbf{T}+\mathbf{R}$ & $\begin{array}{l}\text { ZTR\% } \\
\text { INDEX }\end{array}$ \\
\hline $\begin{array}{l}\text { PAT } \\
\text { S1B }\end{array}$ & 27 & 10 & 1 & - & 4 & 2 & 1 & 1 & 3 & - & - & - & 1 & - & - & 50 & 38 & 76.0 \\
\hline $\begin{array}{l}\text { PAT } \\
\text { S2B }\end{array}$ & 13 & 11 & 2 & - & - & 4 & - & 3 & - & - & 8 & - & 3 & - & - & 44 & 26 & 59.1 \\
\hline $\begin{array}{l}\text { PAT } \\
\text { S5B }\end{array}$ & 4 & 4 & 2 & 1 & 6 & - & 2 & - & 3 & - & 4 & - & - & - & - & 26 & 10 & 38.5 \\
\hline $\begin{array}{l}\text { PAT } \\
\text { S7 }\end{array}$ & 10 & 9 & 2 & 4 & 13 & 10 & 8 & 4 & 8 & 2 & - & - & 4 & - & - & 74 & 21 & 28.4 \\
\hline $\begin{array}{l}\text { PAT } \\
\text { S17B }\end{array}$ & 3 & 4 & 8 & 1 & - & - & 2 & - & 4 & - & - & - & - & - & - & 22 & 15 & 68.2 \\
\hline TOTAL & 57 & 38 & 15 & 6 & 23 & 16 & 13 & 8 & 18 & 2 & 12 & - & 8 & - & - & 216 & 110 & 50.9 \\
\hline$\%$ & 26.4 & 17.6 & 6.9 & 2.8 & 10.6 & 7.4 & 6.0 & 3.7 & 8.3 & 0.9 & 5.6 & - & 3.7 & - & - & \multicolumn{3}{|c|}{$\begin{array}{l}\text { Individual mineral\% } \\
\text { abundance }\end{array}$} \\
\hline
\end{tabular}

Average ZTR\% Index $=54.0 \%$

Total Opaque $=4330$

Total Non-opaque $=216$

Total Non-opaque excluding micas $=204$

\section{Discussion}

The percentage proportions of the non-opaque heavy mineral constituents (Figures 4 and 5) in Lokoja and Patti Formations show the domi- nance of zircon. Tourmaline is the second most abundant of the recovered minerals. Epidote comes next in the Lokoja Formation with staurolite in the Patti Formation. Epidote is present 


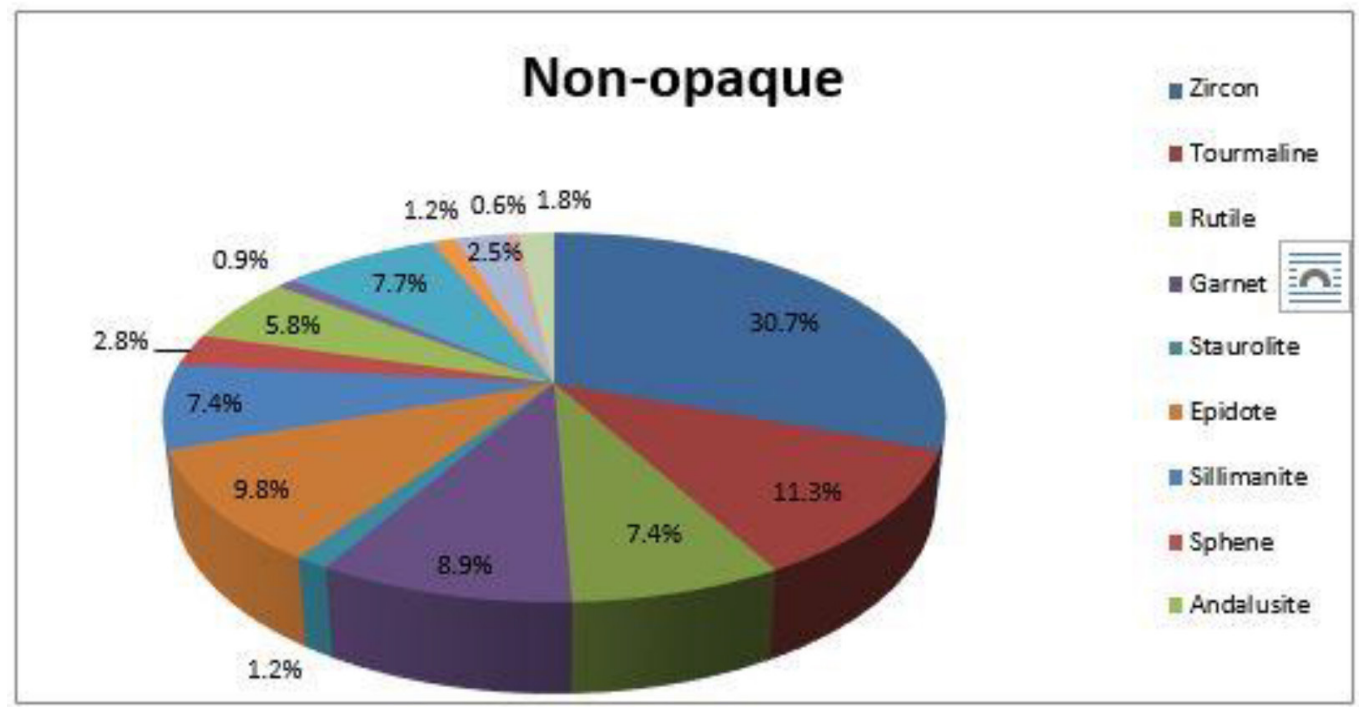

Figure 4: Overall percentage proportion of each non-opaque heavy mineral in the Lokoja Formation.

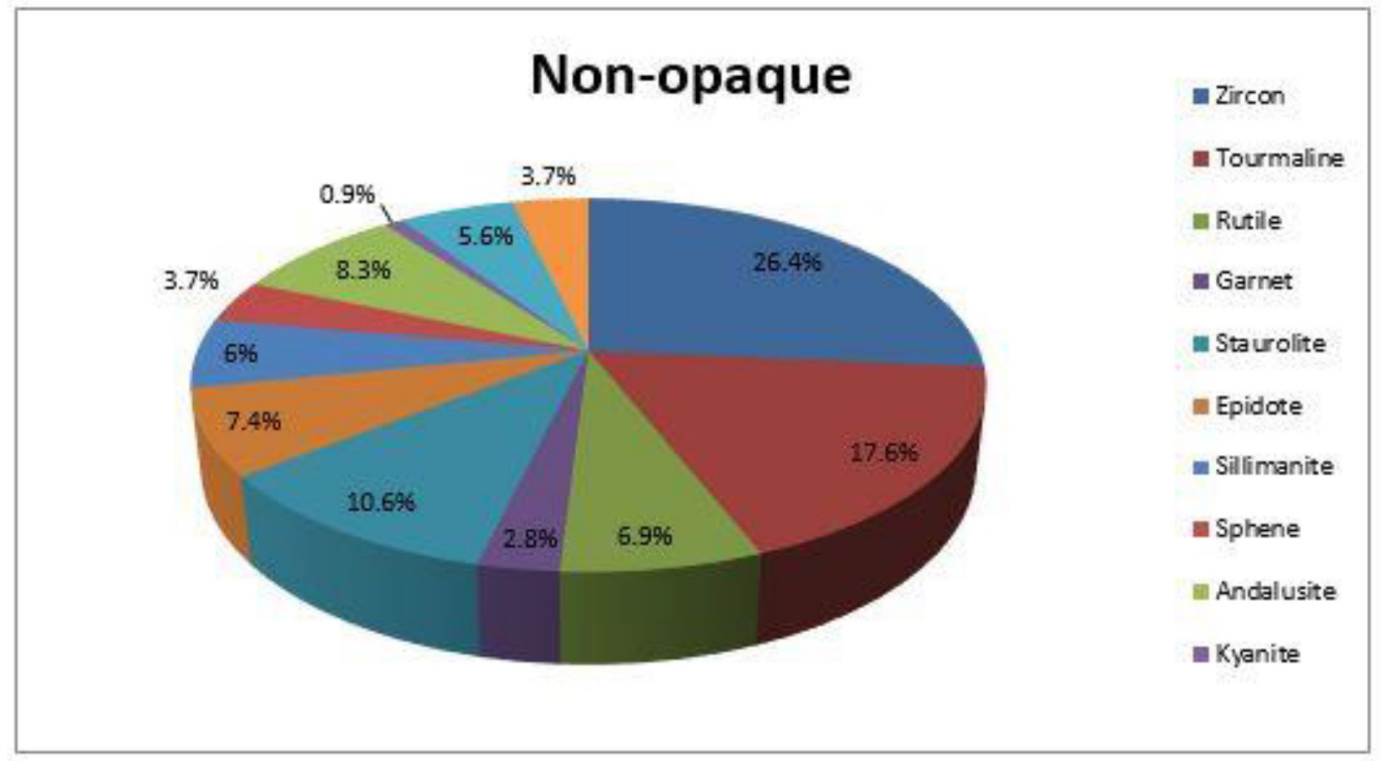

Figure 5: Overall percentage proportion of each non-opaque heavy mineral in the Patti Formation.

in all the samples of the Lokoja Formation but only in three (3) samples of the Patti Formation. Staurolite was recovered in three (3) samples each of the Lokoja and Patti Formations. The minerals with the lowest percentage proportion are cassiterite, staurolite, kyanite and hypersthene in the Lokoja Formation, whereas the lowest in the Patti Formation is kyanite. Cassiterite, lawsonite and hypersthene are totally absent in the Patti Formation. In the heavy mineral stability index of $[24,25]$, hornblende, hypersthene and andalusite are classified as unstable, epidote, kyanite, garnet, sillimanite, titanite, lawsonite, cassiterite as moderately stable, garnet, staurolite as stable and zircon, tourmaline, rutile as ultra-stable minerals. Consequent to the proportion of the constituent heavy mineral in the studied sections, the sediments of the Lokoja and Patti Formations are considered generally stable as they are dominated by ultra-stable and stable minerals. 


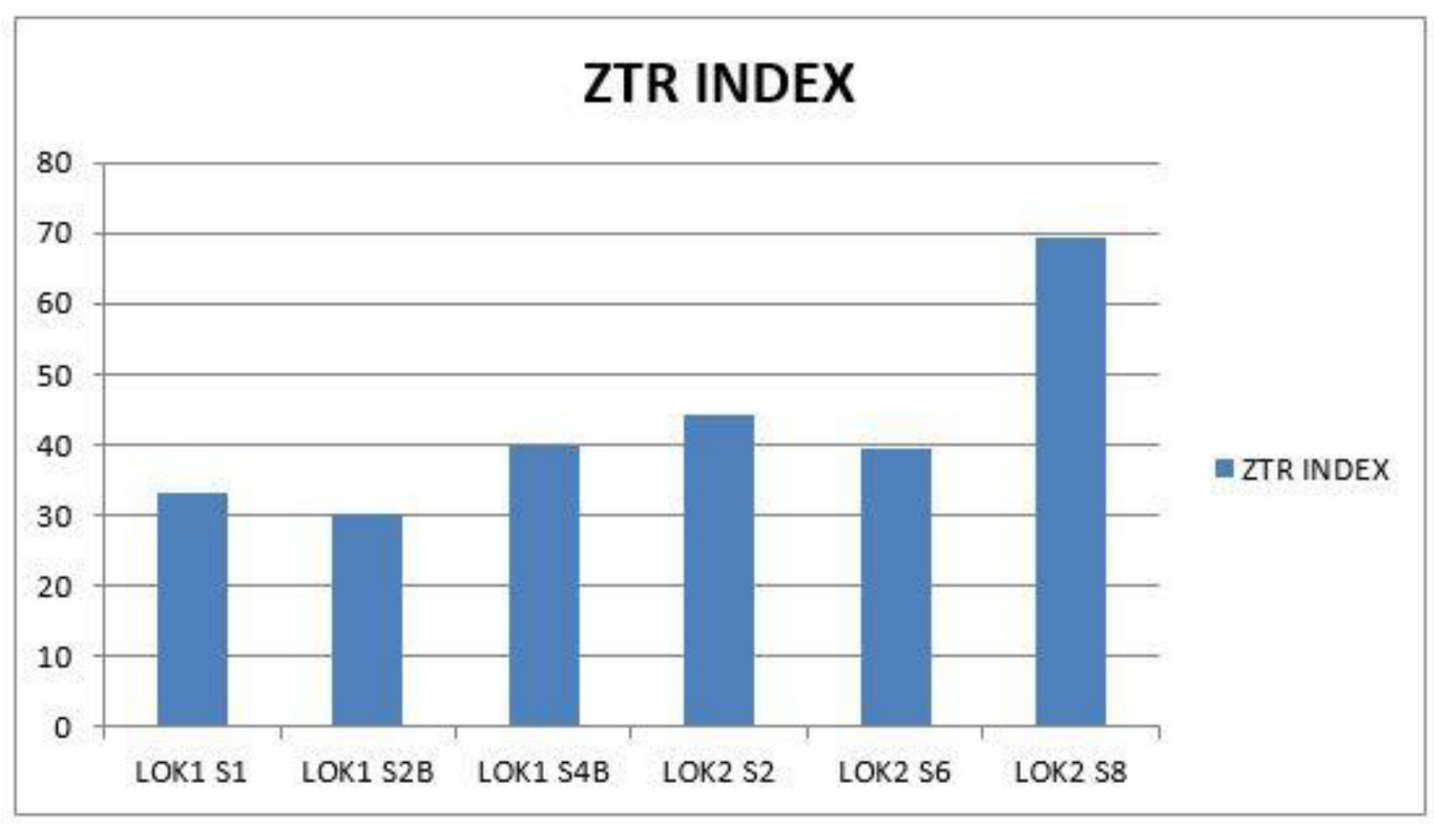

Figure 6: Bar chart of ZTR index of each selected samples of Lokoja Formation.

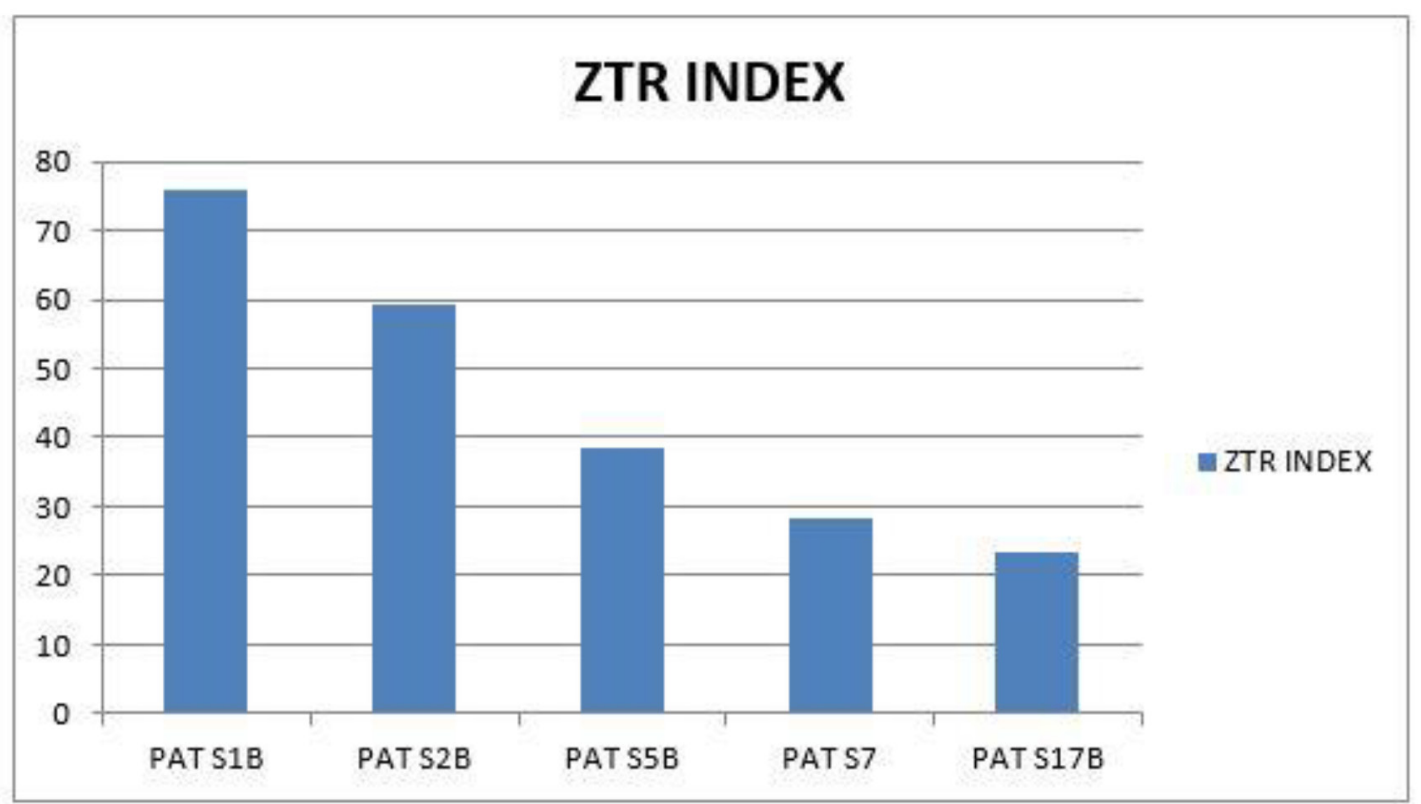

Figure 7: Bar chart of ZTR index of each selected samples of Patti Formation.

The calculated ZTR\% index for the two formations ranges from $30.2 \%$ to $69.4 \%$ in the Lokoja Formation (Figure 6), whereas in the Patti Formation, it ranges from $28.4 \%$ to $76.0 \%$ (Figure 7). All, except one sample from the Lokoja Formation, have ZTR\% index of $<50 \%$. This low ZTR index indicates that the samples of the Lokoja Formation are mineralogically im- mature. The ZTR index of the Patti Formation shows only slight improvement with two samples having ZTR $>50 \%$ and three having ZTR $\%$ index of $<50 \%$. The mean percentage of ZTR index for Lokoja Formation is $42.8 \%$, whereas that of Patti Formation is $54.0 \%$. These show the comparative mineralogical maturity advan- 
tage of the sediments of the Patti Formation over their Lokoja counterparts.

Generally, very few rounded grains were encountered in all the samples studied (Plates 1-14). Most of the grains are either angular or sub-angular, suggesting that the sediments are from nearby sources and may not have been transported far away from weathering location. Hence, indicating textural immaturity of the sediments of both formations.

The abundance of ultra-stable and stable heavy minerals in an assemblage of texturally immature sediments grains (angular to sub-angular) is suggestive of the prevalence of chemical weathering of the source rocks contributing the heavy minerals to the studied formations. Based on the constituent minerals in the studied sediments, mixed source ranging from highto low-grade metamorphic and non-metamorphic sources is suggested. The possibility of contribution from low-grade metamorphic and non-metamorphic sources is indicated with dominance of zircon and tourmaline [26] in the two formations. Mange and Maurer [21] have linked the presence of lawsonite, hypersthene, hornblende, cassiterite, kyanite, andalusite, sillimanite, titanite, epidote, staurolite, garnet to high-grade metamorphic terrain. Also, Diekmann and Kuhn [27] attributed the dominance of low maturity heavy mineral such as green hornblende and garnet to high-grade metamorphic source. Rutile is generally linked to highgrade metamorphic source.

\section{Conclusion}

Heavy mineral analysis of both Lokoja and Patti Formations shows the predominance of non-rounded heavy minerals suites indicating short transport history from the sediment source, probably the southwest and north central Basement Complex terrains. The ZTR indices gave a general evidence of immature sediment suites for the Lokoja and Patti Formations with the latter being more matured than the former. Furthermore, the sediments of both formations are stable as they are dominated by ultra-stable and stable minerals. An assemblage of stable heavy minerals in a suite of texturally immature sediments validates the prevalence of chemical weathering of the source rocks which contributed to Lokoja and Patti Formations. The source of the sediments from both formations is interpreted to be of igneous and metamorphic terrain as indicated by the dominance of zircon, tourmaline, rutile, mica and opaque components.

\section{References}

[1] Obaje, N.G., Moumouni, A., Goki, N.G., Chaanda, M.S. (2011): Stratigraphy, Paleogeography and hydrocarbon resource potentials of the Bida Basin in north-central Nigeria. Journal of Mining and Geology, 47(2), pp. 97-114.

[2] Nwajide, C.S. (2013): Geology of Nigerian Sedimentary Basins. Awka: CSS Bookshop, pp. 227-340.

[3] Wright, J.B., Hastings, D., Jones, W.B., Williams H.R. (1985): Geology and Mineral Resources of West Africa. London: George Allen and Urwin, pp. 90-120.

[4] Udensi, E.E., Osasuwa, I.B. (2004): Spectra determination of depths to magnetic rocks under the Nupe Basin, Nigeria. Nigeria Association of Petroleum Explorationists Bulletin, 17, pp. 22-37.

[5] Ojo, S.B. (1984): Middle Niger Basin revisited: magnetic constraints on gravity interpretations. In: 20th Conference of the Nigeria Mining and Geosciences Society, Nsukka, pp. 52-53.

[6] King, L.C. (1950): Outline and distribution of Gondwanaland. Geological Magazine, 87, pp. 353-359.

[7] Kogbe, C.A. (1981): Geological interpretation of landsat imagery of part of central Nigeria. Journal of Mining and Geology, 28, pp. 66-69.

[8] Braide, S.K. (1992): Syntectonic fluvial sedimentation in the Central Bida Basin. Journal Mining Geology, 28, pp. 55-64.

[9] Olugbemiro, R.O., Nwajide, C.S. (1997): Grain size distribution and particle morphogenesis as signatures of depositional environments of Cretaceous (non-ferruginous) Facies in the Bida Basin, Nigeria. Journal of Mining and Geology, 33, pp. 89-101.

[10] Akande, S.O., Ojo O.J., Erdtmann B.D., Hetenyi, M. (2005): Paleoenvironments, organic petrology and rock-eval studies on source rock facies of the Lower Maastrichtian Patti Formation, Southern Bida Basin, Nigeria. Journal of African Earth Sciences, 41, pp. 394-406.

[11] Idowu, J.O., Enu, E.I. (1992): Petroleum geochemistry of some late Cretaceous shales from the Lokoja Sand- 
stone of Middle Niger Basin, Nigeria. Journal of African Earth Sciences, 14, pp. 443-455.

[12] Ojo, O.J., Akande, S.O. (2006): Sedimentological palynological studies of the Patti Formation, southeastern Bida Basin, Nigeria: Implications for palaeoenvironment and palaeogeography. Nigerian Association of Petroleum Explorationists Bulletin, 19(1), pp. 61-77.

[13] Ojo, O.J., Akande, S.O. (2009): Sedimentology and depositional environments of the Maastrichtian Patti Formation, southeastern Bida Basin, Nigeria. Cretaceous Research, 30, pp. 1415-1425.

[14] Ladipo, O., Akande, S.O., Mucke, A. (1994): Genesis of ironstones from middle Niger sedimentary basin, evidence from sedimentological, ore microscopic and geochemical studies. Journal of Mining Geology, 30, pp. 161-168.

[15] Joshua, E.0., Oyebanjo, O.A. (2009): Distribution of heavy minerals in sediments of Osun River Basin, Southwestern Nigeria. Research Journal of Earth Sciences, 1(2), pp. 74-80.

[16] Sarma, J.N., Chutia, A. (2013): Petrography and heavy mineral analysis of Tipam Sandstones exposed on the Tipam Hill of Sita Kunda area, Upper Assam, India. South East Asian Journal of Sedimentary Basin Research, 1, pp. 28-34.

[17] Ramasamy, P., Karikalan, R. (2010): Distribution and percentage of heavy minerals in coastal geomorphological landforms in Palk Strait, southeast Coast of India. Middle-east Journal of Scientific Research, 5(1), pp. 49-53.

[18] Achab, M., Gutierrez Mas, J.M. (2009): Heavy minerals in modern sediments of the Bay Of Cadiz and the adjacent Continental Shelf (Southwestern Spain): Nature and Origin, Journal of Marine Sciences, 25(2), pp. 27-40.

[19] Grzebyk, J., Leszczynski, S. (2006): New data on heavy minerals from the Upper Cretaceous-Paleogene Flysch of the Beskid Slaski Mts. (Polish Carpathians). Geological Quarterly, 50, pp. 265-280.

[20] Suzuki, T. (1975): Heavy minerals composition of the recent sediments in three different environments in geological survey of Japan, part 1, $501 \mathrm{p}$.

[21] Mange, M.A., Maurer, H.F.W. (1992): Heavy Minerals in Colour. London: Chapman and Hall, $147 \mathrm{p}$.

[22] Lindholm, R.C. (1987): A Practical Approach to Sedimentology. London: Allen and Unwin, $279 \mathrm{p}$.

[23] Hubert J.T. (1962): A Zircon-tourmaline-rutile maturity index and interdependence of the composition of heavy minerals assemblages with the gross composition and texture of sediments. Journal of Sedimentary Petrology, 32, pp. 440-450.
[24] Pettijohn, F.J., Potter, P.E., Siever, R. (1973): Sand and Sandstone. New York: Springer Verlag, 618 p.

[25] Morton, A.C. (1985): Heavy Minerals in Provenance Studies. In: Provenance of Arenites, Zuffa, G.G (ed.). Dordrecht: Reidel, pp. 77-249.

[26] Deer, W.A., Howie, R.A., Zussman, J. (1992): An Introduction to the Rock-Forming Minerals (2nd edition). Essex: Longman, $696 \mathrm{p}$.

[27] Diekmann, B., Kuhn, G. (1999): Provenance and dispersal of glacial-marine surface sediments in the Weddell Sea and adjoining areas, Antarctica: ice-rafting versus current transport. Marine Geology, 158(1-4), pp. 209-231. 


\section{Appendix 1a}

\section{Plates 1-6}

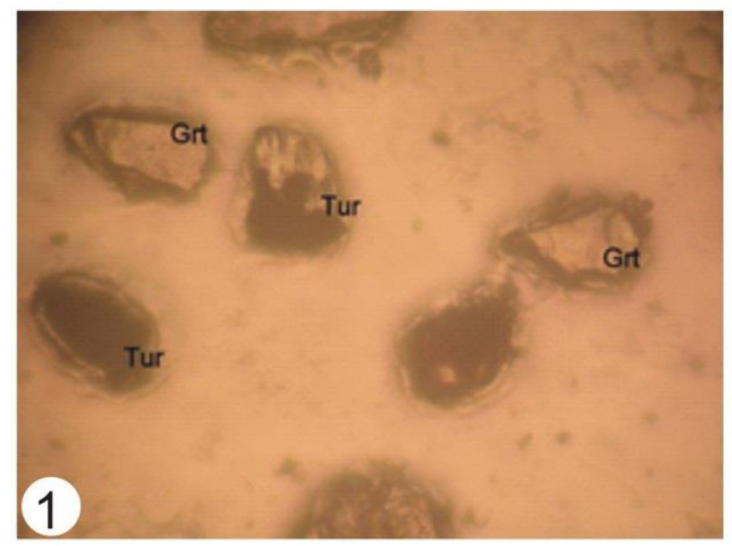

Sample LOK1 S1: Tourmaline (Tur) grains, the lower grain showing secondary growth (overgrowth), Garnet (Grt), Mag. X40

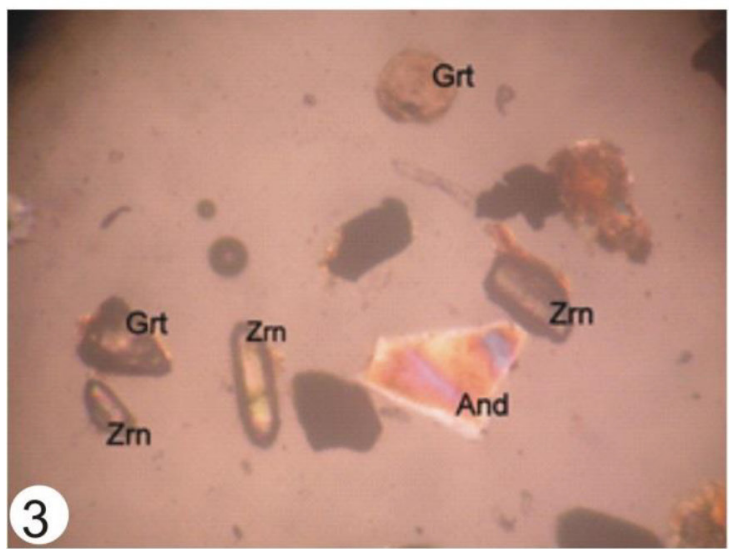

Sample LOK1 S4B: Zircon (Zrn), Garnet (Grt), Andalusite (And). Mag. X40

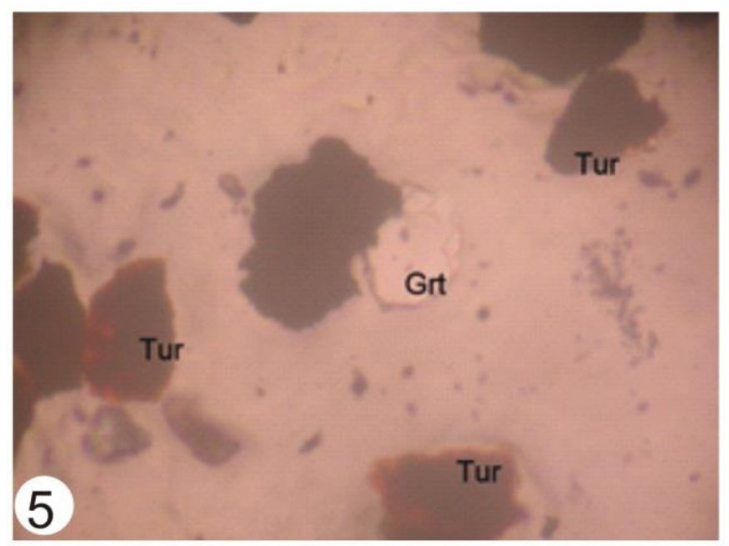

Sample LOK2 S6: Dark Tourmaline (Tur), Garnet (Grt). Mag. X40

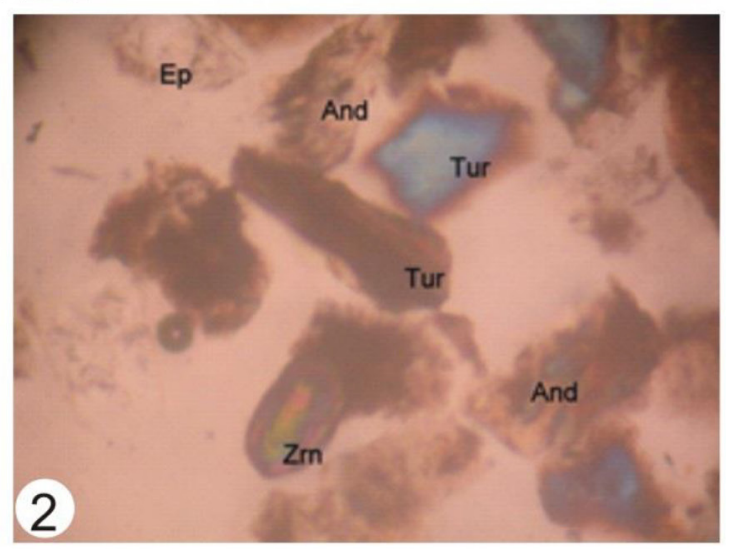

Sample LOK1 S2B: Epidote (Ep), Andalusite (And), Tourmaline (Tur) and Zircon (Zrn). Mag. X40

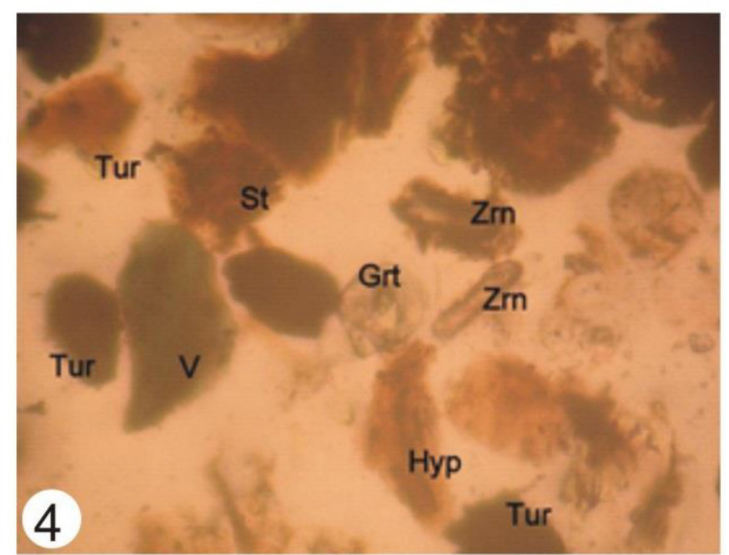

Sample LOK2 S2: Green coloured manganoan variety of Andalusite, Viridine (V), Staurolite (St), brown Tourmaline (Tur), Garnet (Grt), Hypersthene (Hyp), Zircon (Zrn). Mag. X40

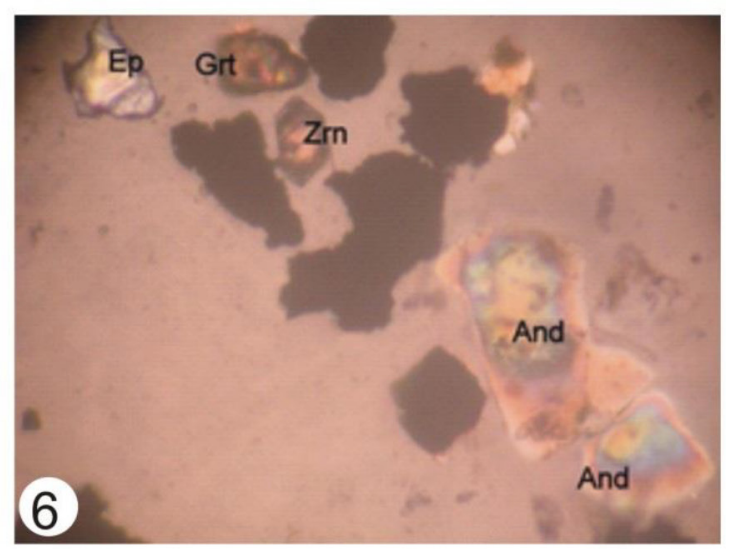

Sample LOK2 S8: Andalusite (And), Epidote (Ep), Zircon (Zrn), Garnet (Grt). Mag. X40 


\section{Appendix 1b}

\section{Plates 7-14}

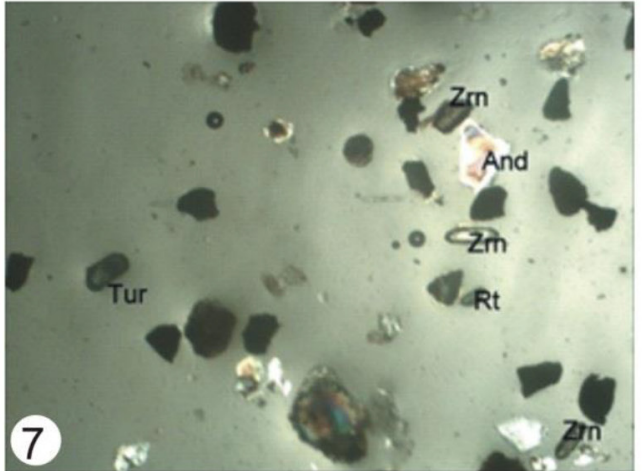

Sample LOK1 S4B: Tourmaline (Tur), Zircon (Zrn), Andalusite (And), Rutile (Rt). Mag. X10

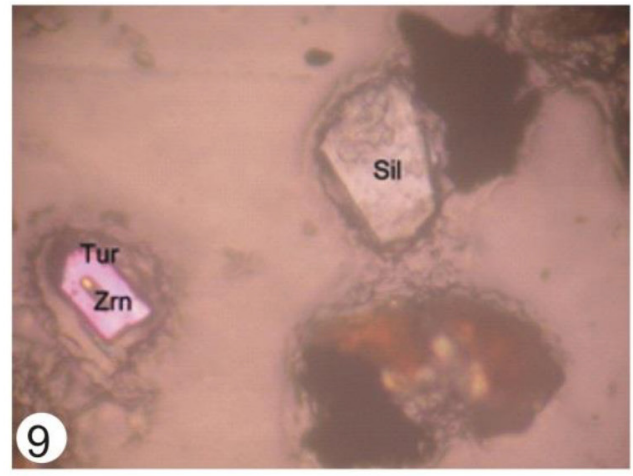

Sample PAT S1B: Sillimanite (Sil), Tourmaline (Tur) with zircon inclusion. Mag. X40

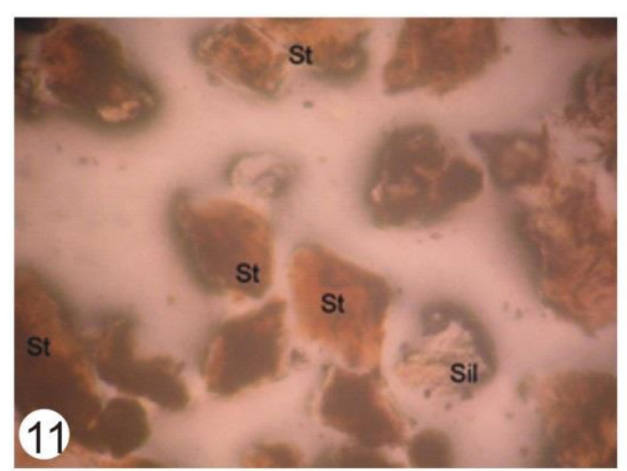

Sample PAT S5B: Staurolite (St), Sillimanite (Sil). Mag. X40

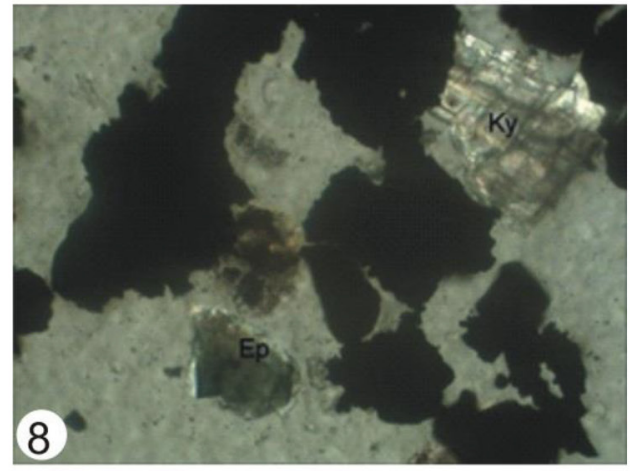

Sample LOK2 S8: Epidote (Ep), Kyanite (KY). Mag. X40

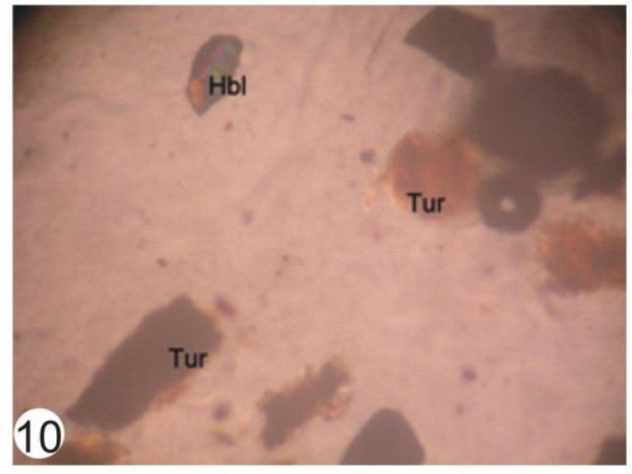

Sample PAT S2B: Hornblemde (Hbl), Tourmaline (Tur). Mag. X40

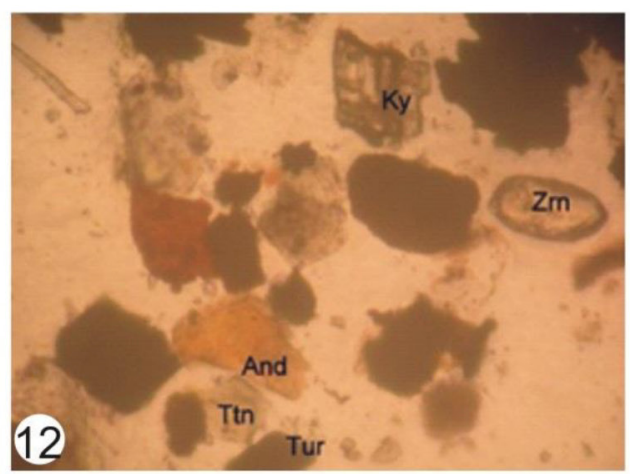

Sample PAT S7: Andalusite (And), Zircon (Zrn), Kyanite (Ky), Titanite (Ttn), Tourmaline (Tur), Mag. X40 


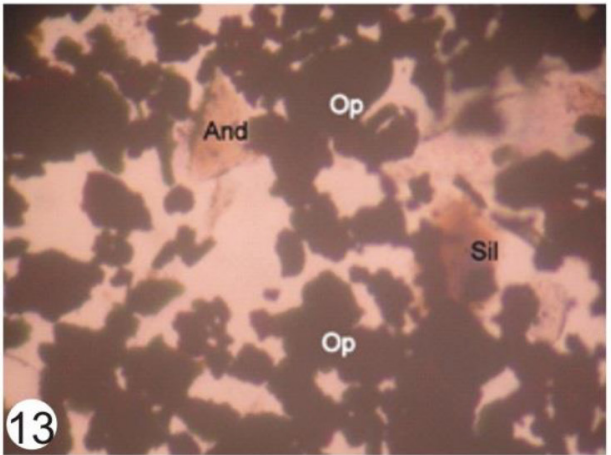

Sample PAT S17B: Andalusite (And), Sillimanite (Sil), Opaque minerals (Opq). Mag. X10

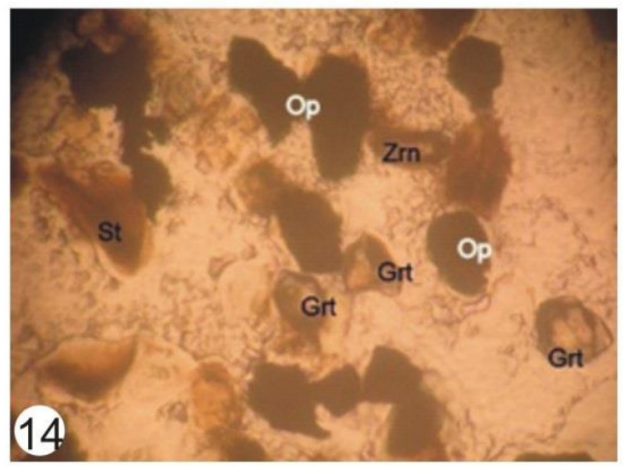

Sample PAT S1B: Staurolite (St), Garnet (Grt), Zircon (Zrn), Opaque minerals (Opq). Mag. X40 